\title{
The Good Life and Climate Adaptation
}

\author{
Udo Pesch
}

check for

Citation: Pesch, U. The Good Life and Climate Adaptation.

Sustainability 2022, 14, 456. https:// doi.org/10.3390/su14010456

Academic Editor: Adriana Del Borghi

Received: 29 September 2021 Accepted: 30 December 2021 Published: 1 January 2022

Publisher's Note: MDPI stays neutral with regard to jurisdictional claims in published maps and institutional affiliations.

Copyright: (C) 2022 by the author. Licensee MDPI, Basel, Switzerland. This article is an open access article distributed under the terms and conditions of the Creative Commons Attribution (CC BY) license (https:// creativecommons.org/licenses/by/ $4.0 /)$.
Faculty of Technology, Policy and Management, Delft University of Technology, 2628 BX Delft, The Netherlands; u.pesch@tudelft.nl

\begin{abstract}
The need to adapt to climate change brings about moral concerns that according to 'ecocentric' critiques cannot be resolved by modernist ethics, as this takes humans as the only beings capable of intentionality and rationality. However, if intentionality and rationality are reconsidered as 'counterfactual hypotheses' it becomes possible to align modernist ethics with the eco-centric approaches. These counterfactual hypotheses guide the development of institutions, so as to allow the pursuit of a 'good life'. This mean that society should be organized as if humans are intentional and, following Habermas's idea of 'communicative rationality', as if humans are capable of collective deliberation. Given the ecological challenges, the question becomes how to give ecological concerns a voice in deliberative processes.
\end{abstract}

Keywords: the good life; climate adaptation; ethics; deliberation; ecological ethics; moral hypotheses; agency; exceptionalism

\section{Introduction}

The changing climate brings about a range of processes of which the severity becomes increasingly clear. The IPCC speaks of disasters like droughts and floods, land degradation, the loss of biodiversity, and so on, all taking place now or in the short term [1]. This calls for firm actions to cope with these consequences of anthropogenic climate change. Most typically these actions to adapt to changing ecological circumstances are framed in technical terms such as 'systems' or 'resilience'. As these terms reveal, climate adaptation measures are usually taken to involve the instrumental manipulation of given parameters. However, these measures also raise ethical questions. Think for instance of the people that need to be dislocated, or that are confronted with new projects like dams or storm surge barriers, or think about those people that have to pay for such adaptation measures [2,3]. In all of these cases, certain people are disadvantaged by these measures and projects, which are issues that inevitably raise questions about the justice and fairness of the distribution between benefits and advantages [4]. It also needs to be established who is responsible for the implementation of these measures. The complication in the realm of climate adaptation is that climate change and its effects pertain to temporal and spatial scales that are not covered by existing institutional settings. For instance, a river may cross different national boundaries, and interventions (or lack thereof) in one state may have effects in another $[5,6]$. As climate adaptation measures affect the lives of people, they also bring about questions related to their ethical and democratic acceptability $[7,8]$. Have the people that are affected by these measures been able to consent to them? Have people had the opportunity to forward their viewpoints, their worries, and their concerns?

Ethical questions related to climate adaptation deal with problems that emerge after the occurrence of environmental change and the depletion of natural resources [9]. This demands the development of alternative approaches that can be added to existing approaches in environmental and climate ethics. A starting point in this is to return to general approaches in academic ethics, as this has developed categorizations and methods to address questions about justice, responsibility, and acceptability. This dominant approach in ethics is to establish evaluative yardsticks to decide upon the goodness of actions, situations, 
and developments. It proves to be difficult, however, to use existing theories to address moral questions that are related to climate change [10]. Two reasons for this difficulty are that these questions are subject to many moral uncertainties [11], and that the categories, frameworks, and theories that are provided by ethics mostly focus on human action and interaction [12]. From David Hume and Immanuel Kant onwards, modernist ethics has been developed as an anthropocentric discipline in which it is taken to be a truism that only humans can be moral or immoral, while the rest of nature is just a-moral. As such, modernist ethics is typically a branch of study that endorses exceptionalism: humans are separated from the rest of nature [13-15]. In recent years, questions about how to account for non-human living beings, such as animals and ecosystems, have been raised [16-18], but these have yet to be applied to the challenge of climate change adaptation.

The question tackled in this article is how to overcome the bias of human exceptionalism in the ethical appraisal of climate-adaptation measures. In answering this question, I will use insights from different disciplinary angles, such as environmental ethics, STS, political theory, and sociology. In the next section, I will outline the work of Donna Haraway and Bruno Latour as the starting point for critique of the anthropocentric bias. The core of this critique is that we need to acknowledge that humans are not separated from nature [19], instead, people form symbiotic networks with nature in which natural entities also have the capacity for agency [20]. Although it is often not acknowledged, I will show in section three that there are lines of thought in modern philosophy and ethics that allow the integration of this challenge to human exceptionalism. I will assemble these lines of thought with the notion of 'the good life', which I understand as the way in which modern society is deliberately shaped by the establishment of institutions that: (1) are based on moral hypotheses about what humans are, ought to be, or could be; (2) allow the further substantiation of these moral hypotheses in institutional re-design. In this I will follow Jürgen Habermas's account of 'communicative rationality', which holds that the capacity of language is crucial, as it allows humans to speak out who they are, what they want, and why they have made certain actions in deliberative processes. To address the eco-centric challenge, it is necessary to think about ways in which we can re-design institutions so to give a voice to nature.

\section{The Eco-Centric Challenge}

Modern philosophy has always been subjected to the critique that it denies the intrinsic connection of humans with nature [21-23]. The current ecological crises give further credence to this critique. To many authors and activists, the dogma of exceptionalism is seen as the root of the ecological crisis of climate change. The 'deep ecology' movement, for instance, aims to replace an anthropocentric outlook with an 'eco-centric' outlook that assumes that both human and non-human life has intrinsic value irrespective of the values humans impose on nature [24,25]. According to this philosophy, it is the instrumental use of non-human life that has led to the negligence and eventually the destruction of ecosystems. As such, modernist ethics may not be the most suitable point of entrance to consider the ethics of climate adaptation: this ethics is part of the problem, and as such cannot and should not be part of the solution. From an eco-centric point of view, it is hubris to restrict ethics to humans. Instead, ethics should acknowledge the fundamental embedment of humans in nature. Our moral considerations should be built on the fact that we are symbiotic with our microbiomes and our ecological environment, and all of our actions have an effect on this intrinsic fabric of life [26].

I will here explore the eco-centric challenge by looking at the work of Donna Haraway and Bruno Latour. These authors may not be direct representatives of the deep ecology philosophy, but come from science and technology studies (STS) and have disputed the anthropomorphism that characterises common understandings of human-technology interaction, by claiming that things and machines are not separated from us, but that we have a reciprocal relation with them $[27,28]$. Especially in their more recent work, both authors 
identify a similar pattern in the relation between human and non-human life that gives the eco-centric challenge a thorough ontological grounding.

The motivation to focus on authors originating from STS emerges from the character of climate adaptation policies, which tend to rely quite heavily on science and technology, while these policies have a direct impact on nature as well. As such, the relation between policies, technology, and nature is central in the development of climate adaptation ethics [29]. However, by focussing on two authors only, it is a matter of fact that my analysis fails to do justice to the richness of eco-centric perspectives in environmental ethics and in non-Western philosophies. The further inclusion of these perspectives would very much be a welcome contribution to climate adaptation ethics.

In her book Staying with the Trouble [30], Haraway argues that we should no longer start from the premise of humans as exceptional beings, but should instead emphasize the kinship between ourselves and our living environment. She states that living beings do not just do things on their own, but always respond to the actions of other living beings. According to Haraway, living organisms are 'response-able': they are creatures that have relationships "crafted in intra-action through which entities, subjects and objects, come into being" [31]. With the activities of all these response-able creatures, a web of coherent relationships is created, in which we humans are only a part. Haraway argues that nature teaches us that as rooted individuals we must take more care of our relationships. Our behaviour within and toward nature should be based on the realization that every action someone undertakes is a response to nature's activities, while this action will also evoke responses by nature.

Bruno Latour is one of the originators of actor network theory (ANT) [28]. In this approach, agency is not only reserved for people, but also for artefacts. Latour looks at things and considers these not as neutral objects, but as actors in a network in which people and things determine each other's actions. While having started with the actions of technologies, the climate crisis showed Latour that nature can be seen as an actor. Further, 'Gaia', Latour's name for everything that lives within the narrow biosphere that encompasses the Earth, can be seen as a network of interdependent actors [32]. The climate problem can be seen as the way Gaia reacts to our industrialized activities [33]. A reaction that creates a new reality, to which we as humans have to respond again. Seeing her as an actor implies that we also have to give Gaia the opportunity to account for herself: to speak out, so to say. This is where, according to Latour, the anthropocentric viewpoint causes problems. This viewpoint presents an objectified account of nature, for instance by turning Gaia, with all of her facets, into a singular entity such as the 'ecosystem'. Such a systemic representation makes it impossible to understand the heterogeneity in which nature reacts to human activities. In other words, we cannot understand what nature is 'saying' if it is seen as an entity that obeys mechanistic laws. As stated above, climate adaptation measures typically maintain such a systemic account of nature, so that its voice is disabled right from the very start. This needs to be overcome, according to Latour, by giving a political voice to everything that is not yet represented in political and institutional fora: technologies and also manifestations of Gaia, such as water, soil, forests and air.

Haraway and Latour emphasize the embeddedness of human life within nature in which actions and responses are intrinsically interconnected. From this starting point, it becomes possible to derive a fundamental critique of modernist ethics, which reproduces the idea that humans are rational and intentional beings-separated from nature.

The presumed human uniqueness evolves from the identification of humans as intentional and rational beings: they are believed to have the ability to choose between different courses of action after having considered the consequences of these courses of actions. However, humans do not 'choose'; they respond in symbiotic relationships with other living beings. In other words, the conceptions of agency and personhood that underlie modern ethics are based on a faulty reading of human nature.

Another point of critique can be articulated in terms of the divide between 'is' and 'ought'. In conventional analytical ethics, the validity of moral claims depends on the extent 
that contingency can be removed. By analytically dissecting arguments and claims, an 'ought' that is independent from an 'is' is believed to remain, as this process eliminates the occurrence of the 'naturalistic fallacy' in which an 'ought' is derived from an 'is' $[15,34]$.

Haraway and Latour see no problem in crossing the divide between 'is' and 'ought'. In fact, they appear to reverse the drift of the original naturalistic fallacy: ethicist tend to derive description of what 'is' from their assumption of what 'ought' to be. By postulating that humans are exceptional because of their intentionality and rationality, ethicists have become blind to the moral role of nature. As such, ethicists appeared to have maintained the opposite of the 'naturalistic fallacy', something that could be called the 'idealistic fallacy' — which, tellingly, appears to be a notion that hitherto no one has ever thought of.

\section{The Good Life}

Haraway and Latour teach us that humans are intrinsically connected to the biosphere, which compels us to reconsider the anthropocentrism of conventional ethics. Though this is a legitimate starting point, especially given all of the ecological disasters that we are currently facing, it may also overlook ethical perspectives that very much align with their approach. Part of the appeal of Haraway and Latour lies in their provocative style, however, this style sometimes leaves the impression that they insinuate that all modern thinkers entertain the same understanding of human agency and personhood [35,36] — jettisoning the learnings of modern philosophy that are useful also for an eco-centric ethics.

Here I will outline an alternative take on ethics that might be suitable for dealing with ecological threats such as climate change. I derive the name of this alternative approach from Aristotle's notion of the 'good life', emphasizing the need to include the full range of life, viz. the whole the biosphere, in ethical considerations. Granted, this contradicts Aristotle, as he based the 'good life' precisely on the distinction between humans and nature that has been reproduced in modern ethics: to him, what defines humans (or at least citizens) is their capability to choose, while animals are destined to act on instinct [37]. What I will use from Aristotelian ethics is what he considered to be the goal of a political community, which is that it should allow its members to cultivate their virtues in the best possible way.

Before the biosphere can become integrated into our account of the good life, the Aristotelian ideas also need to be modified to fit modernity. After all, for Aristotle the political community was the aristocratic city state, in which membership was restricted to a limited number of citizens. The states that emerged after the Enlightenment period can be characterized as complex societies in which equality is pursued [38,39]. As such, I propose that the good life in modernity revolves around the organization of society by establishing and maintaining the institutions that allow us to make the best moral judgments [40]. These judgments not only pertain to our private decisions, but also to the organization of society by collective processes of deliberation. In other words, there is an ongoing dialectical relation between setting up the right institutions by collective deliberation and the nurturing of the capacity to deliberate by setting up the right institutions.

In the modern pursuit of the good life, the primary role of ethics is to provide the starting points that allow the establishment of institutions. It is important to emphasize that these starting points are not fully developed, but function as 'moral hypotheses' which are further substantiated in the continuing evolution of institutions. During this evolution, ethics can help out in the further articulation of these starting points, so to feed into the deliberative processes that address the (re-)design of institutions. This means that the role of ethics is not to uncover moral truths, but to forward and fine-tune moral hypotheses in their reciprocal relation with institutions. As such, ethics has a constructive and active role in the ongoing project of the good life, instead of merely providing evaluative yardsticks.

In this, institutions can be taken very broadly, the notion includes judicial laws, cultural norms, state policies, and governance structures, but also technological artefacts and infrastructures. All these can be seen as rules in themselves or as structures that forward rules that guide human behaviour, so that societal order can be created [41-43]. 
To grasp the account of the good life developed here, it makes sense to start with the moral hypotheses articulated by Immanuel Kant, because these may be the most decisive contributions to the design of institutions by specifying a distinct moral understanding of humans. Kant postulated individuals as intrinsically autonomous and rational: they are capable of making decisions after thinking about the options and possible consequences [44]. Humans can separate themselves from their immediate position and reflect on their actions, so to determine the morally best option, and they can give reasons to others to explain why they have opted for a specific decision. With that, individuals can be held accountable for their decisions. As Kant saw autonomy and rationality as defining traits of humans, his philosophy is also radically egalitarian: all individuals are to be taken as autonomous and rational, and as such each deserves to be dignified as an individual human.

This clearly anthropocentric position explains why Kant is often seen as hostile to environmental concerns [45]. However, it seems sensible to see Kant's description of autonomy and rationality not as outcomes, but as ethical starting points that demand continuous reassessment $[40,46]$. We have to ask ourselves can we make institutions based on autonomy and rationality? And if so, how can we make them work? In other words, autonomy and rationality are neither 'ought's' nor 'is's', instead they are counterfactuals revolving around this question: assume that if they were true, what would that mean for the design of institutions? If institutions are designed to cater to these counterfactuals, the moral potential of humans can be effectuated in real life.

Kant's ethical starting points form the basis of Enlightenment institutions such as the legal system, parliamentary democracy, modern science, and the free market. All of these institutions are based on the relation between individuals that can be held responsible for the actions and decisions they have made $[47,48]$. In this, it is illustrative to have a closer look at the legal system [49], which I think is representative of the way that modern institutions function in many accounts. Admittedly ignoring the variety of jurisdictions and legal traditions, courts in Western democracies can be characterized as follows: they are institutions in which individuals that have transgressed existing laws are asked to explain how they have come to these transgressions. The ideal is that if these explanations show that the person who is on trial could not have chosen otherwise, she will be acquitted-though this ideal often cannot be met because of practical and theoretical complexities [50,51]. In other words, the presence of a court of law allows individuals to be held responsible for their actions, thereby informing these individuals what actually counts as good behaviour and good reasons [52]. What is also emblematic is that legal systems in Western democracies are very much based on ongoing jurisprudence. Over time judges have constantly adjusted their assessments because of changed moral and empirical insights about what is to be seen as an 'individual person', an 'intention', or a 'good reason' [53,54]. Indeed, ethical starting points have changed over time, think, for instance, how until the eighteenth century animals had been put on trial, or how progress in criminology and psychology have led to revised accounts of personhood and agency. We can see similar kinds of progress in other domains, for instance, consider universal suffrage, which has been the result of the efforts of a variety of emancipatory movements. In fact, in Kant's time it would be normal to see only men from a certain class and race as autonomous and rational individuals; today this would be an absurdity. Clearly the egalitarian principle that Kant articulated has been subject to revision, the conviction that 'all men are equal' still holds, but who are to be included as 'men' and what 'equality' means have radically changed.

I do not want to suggest that the moral project of the good life can be seen as a homogeneous development, in which Kant's ideas are gradually given a more defined shape. There are many institutions which may bring forward contrastive conceptions of personhood and agency. There is a heterogeneity of sets of values that are often conflicting. There is no clear direction, but an ongoing process of contestation and resolution in which new conceptions of moral principles are temporarily articulated [4]. 


\section{Revising Personhood and Agency}

Climate change figures as a fundamental call to revise our institutions and our conceptions of personhood and agency. Instead of being separated from the biosphere, humans are intrinsically part of it. The need to revise institutions is especially pressing because our current institutions do not fit the temporal, spatial, and cognitive scale that a problem like climate change demands. Moreover, from the take on the good life developed here, we can see climate adaptation not as a technical or a policy matter, but as a demand to adapt dominant conceptions of what personhood and agency mean.

I think that insights by Haraway and Latour are helpful for this, but in their vigour to debunk the achievements of modernity, they are unable to align their work with the ethical starting points of autonomy and rationality. However, as said above, the intentionality of an individual can best be seen as a counterfactual assumption: it is an assumption that makes it possible to hold each other accountable for our decisions afterwards. Then we are forced to give good reasons that could have counted as intentions had we been wholly intentional beings.

The importance of this reading becomes clear if we look at the related problem of 'rationality'. Here, Haraway or Latour seem to identify 'rationality' with 'instrumental rationality', which involves finding the right means for particular ends. It is a form of rationality that we see in the technocratization and bureaucratization of daily life. This suggests that meanings are imposed upon our actions from an objectified way of thinking; where it concerns our interactions with nature, nature becomes a means to achieve a specific goal, for example by supplying the raw materials for products. This instrumental view aligns with a mechanistic representation of nature, in which nature is seen as a system that consists of analytically distinct blocks that influence each other according to the laws of nature. Haraway and Latour have great difficulty with this mechanistic view because it offers no possibility to let nature itself answer [30,32]. Certainly if nature is seen primarily as an instrumental resource, we are asking for problems.

Though instrumental rationality is the dominant way of conceiving rationality, it is by no means necessary to restrict rationality to instrumental rationality. If we look at Max Weber's idea of rationality, it is not just about instrumental objectification, but also about making rules, values, goals, and means explicit, so that motivations and actions can be accounted for transparently [55]. In other words, rationality refers to the ability to put thought into words and to let those words be part of a dialogue. This creates a form of rationality that Jürgen Habermas has called 'communicative', and that coexists with instrumental rationality [56]. The status of communicative rationality is often not acknowledged, nevertheless it has been vital to the way in which modern institutions and democratic politics are organized [57].

Habermas's idea of communicative rationality is fully intertwined with the idea of counterfactual intentionality. It forces a person to make her motivations explicit, so that these can be discussed and a collective judgment can be formed: what is considered to be a good reason is established within a certain institutional context. The importance is that with the possibility of confronting someone afterwards about their choices, ethical frameworks have been developed that are based on the primacy of the individual. As such, this version of rationality is closely aligned with Kant's counterfactual starting points of autonomy and intentionality.

In communicative rationality, language is decisive. Language provides us with the ability to articulate our motives, to communicate with each other, to give and share meanings, and to introduce and preserve new concepts. It could also be said that our ethical [58] and political systems are language-centric rather than anthropocentric. What singles out humans is their capacity for speech, which according to Hannah Arendt [59] is the ultimate foundation for political 'action' - that is the deliberative processes that are associated with the pursuit of the good life, which according to Arendt are the normative ideal of any democracy. This means that while we constitute networks with everything that lives in and around us, as Haraway states, humans are still the only parts that are able to speak out, 
while beings and things do not have this ability —at least not to the extent that humans have [60].

This does not necessarily bring about a fundamental problem. This becomes clear if one considers the fact that there are also many humans that do not have a voice while being affected by our current actions, future generations being the most striking example. Democratic institutions are based on representativeness, only those agents that can actively express their needs or wants are taken into consideration. Only if groups of people organize themselves to represent non-vocal or not-yet-vocal beings can the concerns of these beings be taken into consideration. However, in other ways humans are often not able to express themselves on matters that concern them. The way that democratic decision-making processes are organized mostly allows access by those actors who have the resources to speak, while many groups remain marginalized [61]. Another problem arises from the dominant role of instrumental rationality described above, in which reality is described in an objectified and mechanized way, which most basically means that what counts as good reasons becomes fixated from an externalized point of view. If such a description is taken as accurate, people have no chance to form their own meanings and they cannot amend what counts as good reasons. This also sets aside the possible plurality of cultures, perspectives, and principles for a singular system of meaning, while communicative rationality is about the development of a dialogical format that allows the confrontation of world views that are made explicit and justified.

Illustrative here is the institutional domain of the free market, as this domain displays many of the pathologies that are of concern here. The free market can be seen as one of the key institutional domains in modernity that secures the autonomy of individuals, and in doing so allows for general economic prosperity. In an idealized world, the competitive market produces a deeply egalitarian system, granting individuals equal rights and opportunities. However, over time the conception of 'individuals' has changed into 'legal persons', including not only humans, but also organizations, such as firms [62]. This implies that currently the free market assumes a level playing field between individual persons, such as consumers or labourers, and firms, such as multinationals. Though these firms do not have the power of speech, they have more than enough other powers to compensate for that deficiency.

The legitimization of this broad conception of personhood follows from the promise of general prosperity and economic growth. Indeed, the free market has provided an extremely high level of affluence, but it has also contributed to economic inequality and the profound disruption of ecosystems as nature is converted into economic resources. The development of technology along the lines of instrumental rationality, as discussed above, follows this disruptive logic of the free market [63]. Indeed, it can be said that the market has taken away the voices of many humans and leaves no room for nature to express its wants and needs in any way whatsoever.

While granting firms personhood can be said to have led to devastating effects, it also shows that non-human entities indeed can be taken into consideration as persons-a point that has been advocated, for instance, by Christopher Stone [64], who rhetorically asked Should trees have standing? $[65,66]$. In all, much more reflexivity and flexibility can be utilized than is usually assumed. The approach of the good life does not oppose articulations of personhood and agency that give a voice to nature.

\section{Conclusions: Rethinking Climate Adaptation}

Glenn Albrecht writes that: "democracy is, by definition, anthropocentric, and capable only of partial answers to human-biased questions concerning the body politic. That Human bias is now revealed as its greatest weakness as the multiple crises enveloping the planet require global answers that must incorporate non-human life in all of its forms" [26]. This paper has tried to address this challenge by exploring how climate adaptation demands not only the restructuring of physical infrastructures, but also the adaptation of existing ethical and institutional frameworks. In this, humans and non-humans have to be given a 
language so they can manifest their counterfactual agency and personhood through the appropriate institutions. This allows the maintenance of the achievements of modern ethics while addressing the eco-centric challenge. Indeed, such an approach seems completely in line with Latour's views, despite all of his harsh criticism of modern thinking. Most basically, Latour argues for participation through a fairly traditional way of parliamentary or institutional representation, in which voters speak for beings, things and voiceless people. In doing so, he trusts that a multitude of representative voices creates an effective barrier against the objectifying tendencies of instrumental rationality. A plurality of voices ensures that the actions and responses of non-linguistic beings also find a place in political and moral discussions. At the same time, it is questionable whether we can give nature a voice without having scientific, that is objectified, descriptions of nature [26]. One cannot but acknowledge this tension.

Another tension is that between 'invited' and 'uninvited' participation [67,68]. In democratic decision-making processes, citizens do not speak out only within the setting of existing procedures, but also (and even more so) in public discourse that is fundamentally disorganized [69]. Concerns, values, and preferences often become articulated outside of existing institutional frameworks as a response to those concerns, values, and preferences that have already been institutionalized [70,71]. In fact, it is one of the key characteristics of liberal democracy that civil society is authoritative for formal institutions [72]. How to give such authority to non-discursive beings is an open question; perhaps Haraway's emphasis on care will help out here, if we realize and experience that we are fully embedded in nature, we will adjust our norms, values, and orientations. These tensions need to be acknowledged and addressed in order to pursue the good life. Our prevailing ethical starting points need to be revisited, so to improve the quality of life-with life taken as broadly as possible.

Funding: This research received no external funding.

Institutional Review Board Statement: Not relevant.

Informed Consent Statement: Not relevant.

Data Availability Statement: Not relevant.

Conflicts of Interest: The author declares no conflict of interest.

\section{References}

1. IPCC. Special Report; Climate Change and Land. Available online: https://www.ipcc.ch/srccl/ (accessed on 29 September 2021).

2. Warner, J.F.; Wiegel, H. Displacement Induced by Climate Change Adaptation: The Case of 'Climate Buffer' Infrastructure. Sustainability 2021, 13, 9160. [CrossRef]

3. Doorn, N.; Brackel, L.; Vermeulen, S. Distributing Responsibilities for Climate Adaptation: Examples from the Water Domain. Sustainability 2021, 13, 3676. [CrossRef]

4. Pesch, U. Institutions of justice and intuitions of fairness: Contesting goods, rules and inequalities. Crit. Rev. Int. Soc. Political Philos. 2021, 1-14, ahead of print. [CrossRef]

5. Renner, T.; Meijerink, S. Policy entrepreneurs in international river basins-Getting climate adaptation on the cross-border water policy agenda. Reg. Environ. Chang. 2018, 18, 1287-1298. [CrossRef] [PubMed]

6. Jacobs, J. Spatial planning in cross-border regions: A systems-theoretical perspective. Plan. Theory 2014, 15, 68-90. [CrossRef]

7. Taebi, B. Bridging the gap between social acceptance and ethical acceptability. Risk Anal. 2016, 37, 1817-1827. [CrossRef]

8. Sarzynski, A. Public participation, civic capacity, and climate change adaptation in cities. Urban Clim. 2015, 14, 52-67. [CrossRef]

9. Byskov, M.F.; Hyams, K.; Satyal, P.; Anguelovski, I.; Benjamin, L.; Blackburn, S.; Borie, M.; Caney, S.; Chu, E.; Edwards, G. An agenda for ethics and justice in adaptation to climate change. Clim. Dev. 2021, 13, 1-9. [CrossRef]

10. Gardiner, S.M. A Perfect Moral Storm: The Ethical Tragedy of Climate Change: The Ethical Tragedy of Climate Change; Oxford University Press: New York, NY, USA, 2011.

11. Taebi, B.; Kwakkel, J.H.; Kermisch, C. Governing climate risks in the face of normative uncertainties. Wiley Interdiscip. Rev. Clim. Chang. 2020, 11, e666. [CrossRef]

12. Hampshire, S. Morality and pessimism. In Public and Private Morality; Hampshire, S., Ed.; Cambridge University Press: Cambridge, UK; New York, NY, USA; Melbourne, Australia; Sydney, Australia, 1972; pp. 1-22.

13. Ehrenfeld, D.W. The Arrogance of Humanism; Oxford University Press: New York, NY, USA, 1981. 
14. Peterson, A.L. Not of the World: Human Exceptionalism in Western Tradition. In Being Human; University of California Press: Oakland, CA, USA, 2001; pp. 28-50.

15. Jonas, H. The Imperative of Responsibility: In Search of an Ethics for the Technological Age; University of Chicago Press: Chicago, IL, USA, 1985.

16. Hickey, C.; Robeyns, I. Planetary justice: What can we learn from ethics and political philosophy? Earth Syst. Gov. 2020, 6, 100045. [CrossRef]

17. Dryzek, J.S.; Pickering, J. The Politics of the Anthropocene; Oxford University Press: New York, NY, USA, 2018.

18. White, L. The historical roots of our ecologic crisis. Science 1967, 155, 1203-1207. [CrossRef]

19. Latour, B. Agency at the Time of the Anthropocene. New Lit. Hist. 2014, 45, 1-18. [CrossRef]

20. Nash, L. The agency of nature or the nature of agency? Environ. Hist. 2005, 10, 67-69.

21. Habermas, J. Der Philosophische Diskurs der Moderne; MIT Press: Cambridge, MA, USA, 1987.

22. Taylor, C. Sources of the Self. The Making of the Modern Identity; Harvard University Press: Cambridge, UK; London, UK, 1989.

23. De Geus, M. Ecotopia, sustainability, and vision. Organ. Environ. 2002, 15, 187-201. [CrossRef]

24. Sessions, G. The deep ecology movement: A review. Environ. Rev. 1987, 11, 105-125. [CrossRef]

25. Naess, A. The shallow and the deep, long-range ecology movement. A summary. Inquiry 1973, 16, 95-100. [CrossRef]

26. Albrecht, G.A. Negating solastalgia: An emotional revolution from the Anthropocene to the Symbiocene. Am. Imago 2020, 77, 9-30. [CrossRef]

27. Haraway, D. A cyborg manifesto: Science, technology, and socialist-feminism in the late 20th century. In The International Handbook of Virtual Learning Environments; Springer: Berlin/Heidelberg, Germany, 2006; pp. 117-158.

28. Latour, B. Where are the missing masses? The sociology of a few mundane artifacts. Shap. Technol. Build. Soc. Stud. Sociotech. Chang. 1992, 1, 225-258.

29. Brackel, L. Continuous Negotiation in Climate Adaptation: The Challenge of Co-Evolution for the Capability Approach to Justice. Sustainability 2021, 13, 13072. [CrossRef]

30. Haraway, D.J. Staying with the Trouble: Making Kin in the Chthulucene; Duke University Press: Durham, NC, USA, 2016.

31. Haraway, D.J. When Species Meet; University of Minnesota Press: Minneapolis, MN, USA, 2013; Volume 3.

32. Latour, B. Facing Gaia. In Six Lectures on the Political Theology of Nature', Gifford Lectures on Natural Religion; University of Edinburgh: Edinburgh, Scotland, 2013; pp. 18-28.

33. Latour, B. Down to Earth: Politics in the New Climatic Regime; John Wiley \& Sons: Hoboken, NJ, USA, 2018.

34. Nolt, J. The move from good to ought in environmental ethics. Environ. Ethics 2006, 28, 355-374. [CrossRef]

35. Latour, B. We Have Never Been Modern; Harvard University Press: Cambridge, MA, USA, 1993.

36. Betcher, S. Putting My Foot (Prosthesis, Crutches, Phantom) Down: Considering Technology as Transcendence in the Writings of Donna Haraway. Women's Stud. Q. 2001, 29, 35-53.

37. Aristotle. Nicomachean Ethics; Oxford University Press: New York, NY, USA, 2016.

38. Walzer, M. Spheres of Justice. A Defense of Pluralism and Equality; Basic Books: Philadelphia, PA, USA, 1983.

39. Dumont, L. From Mandeville to Marx. The Genesis and Triumph of Economic Ideology; Chicago University Press: Chicago, IL, USA; London, UK, 1977.

40. Benhabib, S.I. Judgment and the Moral Foundations of Politics in Arendt's Thought. Political Theory 1988, 16, 29-51. [CrossRef]

41. North, D.C. Institutions, Institutional Change and Economic Performance; Cambridge University Press: Cambridge, UK, 1990.

42. Durkheim, E. Emile Durkheim on Morality and Society; University of Chicago Press: Chicago, IL, USA; London, UK, 1973.

43. Pesch, U. Tracing discursive space: Agency and change in sustainability transitions. Technol. Forecast. Soc. Chang. 2015, 90, 379-388. [CrossRef]

44. Kant, I. Kritik der Praktischen Vernunft von Immanuel Kant; Georg Reimer: Berlin, Germany, 1788.

45. Lucht, M. Does Kant Have Anything to Teach Us about Environmental Ethics? Am. J. Econ. Sociol. 2007, 66, 127-149. [CrossRef]

46. Arendt, H. The Life of the Mind: The Groundbreaking Investigation on How We Think; HMH: Boston, MA, USA, 1981.

47. Pesch, U. Sustainable development and institutional boundaries. J. Integr. Environ. Sci. 2014, 11, 39-54. [CrossRef]

48. Pesch, U.; Huijts, N.M.A.; Bombaerts, G.; Doorn, N.; Hunka, A. Creating 'Local Publics': Responsibility and Involvement in Decision-Making on Technologies with Local Impacts. Sci. Eng. Ethics 2020, 26, 2215-2234. [CrossRef]

49. Friedman, L.M. The Legal System: A Social Science Perspective; Russell Sage Foundation: New York, NY, USA, 1975.

50. Bovens, M.A.P. The Quest for Responsibility: Accountability and Citizenship in Complex Organisations; Cambridge University Press: Cambridge, UK, 1998.

51. Van de Poel, I.; Royakkers, L. Ethics, Technology and Engineering; Blackwell: Oxford, UK, 2011.

52. Dewey, J. Human Nature and Conduct; Courier Corporation: North Chelmsford, MA, USA, 1922.

53. Hart, H.L.A. Punishment and Responsibility: Essays in the Philosophy of Law; Oxford University Press: New York, NY, USA, 2008.

54. Santoni de Sio, F.; Di Nucci, E. Pushing the Margins of Responsibility: Lessons from Parks' Somnambulistic Killing. Neuroethics 2018, 11, 35-46. [CrossRef]

55. Schreurs, P. Enchanting Rationality. An Analysis of Rationality in the Anglo-American Discourse on Public Organization; Eburon: Delft, The Netherlands, 2000.

56. Habermas, J. The Theory of Communicative Action: Volume 2: Lifeword and System: A Critique of Functionalist Reason; Beacon Press: Boston, MA, USA, 1985; Volume 2. 
57. Cuppen, E.; Pesch, U. How to Assess What Society Wants? The Need for a Renewed Social Conflict Research Agenda. In $A$ Critical Approach to the Social Acceptance of Renewable Energy Infrastructures: Going Beyond Green Growth and Sustainability; Batel, S., Rudolph, D., Eds.; Springer International Publishing: Cham, Switzerland, 2021; pp. 161-178.

58. Henrich, J. The Secret of Our Success: How Culture Is Driving Human Evolution, Domesticating Our Species, and Making Us Smarter; Princeton University Press: Princeton, NJ, USA, 2017.

59. Arendt, H. The Human Condition; University of Chicago Press: Chicago, IL, USA; London, UK, 1958.

60. Wrangham, R. The Goodness Paradox: How Evolution Made Us Both More and Less Violent; Profile Books: London, UK, 2019.

61. Geukes, H.; Pesch, U.; Correljé, A.; Taebi, B. A Healthy Metaphor? The North Sea Consultation and the Power of Words. Sustainability 2021, 13, 12905. [CrossRef]

62. Pesch, U. The Predicaments of Publicness. An Inquiry into the Conceptual Ambiguity of Public Administration; Eburon: Delft, The Netherlands, 2005.

63. Pesch, U. Paradigms and paradoxes: The futures of growth and degrowth. Int. J. Sociol. Soc. Policy 2018, 38, 1133-1146. [CrossRef]

64. Stone, C.D. Should Trees Have Legal Standing? Law, Morality, and the Environment; Oxford University Press: New York, NY, USA, 2010.

65. Mancuso, S. The Nation of Plants; Other Press, LLC.: New York, NY, USA, 2021.

66. Gilissen, H.K.; Suykens, C.; Kleinhans, M.; van Rijswick, M.; van der Werf, K. Towards a rights-based approach in EU international river basin governance? Lessons from the Scheldt and Ems Basins. Water Int. 2019, 44, 701-718. [CrossRef]

67. Cuppen, E. The value of social conflicts. Critiquing invited participation in energy projects. Energy Res. Soc. Sci. 2018, 38, 28-32. [CrossRef]

68. Wynne, B. Public participation in science and technology: Performing and obscuring a political-conceptual category mistake East Asian Sci. Technol. Soc. 2007, 1, 99-110. [CrossRef]

69. Pesch, U. Elusive publics in energy projects: The politics of localness and energy democracy. Energy Res. Soc. Sci. 2019, 56, 101225. [CrossRef]

70. Pesch, U.; Correljé, A.; Cuppen, E.; Taebi, B. Energy justice and controversies: Formal and informal assessment in energy projects. Energy Policy 2017, 109, 825-834. [CrossRef]

71. Callon, M. An essay on framing and overflowing: Economic externalities revisited by sociology. Sociol. Rev. 1998, 46, 244-269. [CrossRef]

72. Taylor, C. Modern social imaginaries. Public Cult. 2002, 14, 91-124. [CrossRef] 